\title{
SIMULASI APLIKASI INTERAKTIF PhET BAGI SISWA SMA PLUS NUSA TIMOR
}

\author{
Godelfridus Hadung Lamanepa'), Petrus Ola Begu'), Oktavianus Ama Ki'i'i), Rosenti Pasaribu ${ }^{4)}$ \\ 1)Pendidikan Fisika, FKIP, Universitas Katolik Widya Mandira, Kupang, NTT, Indonesia \\ Corresponding author : Godelfridus Hadung Lamanepa \\ E-mail : godelfridus29lamanepa@gmail.com
}

Diterima 27 Oktober 2020, Direvisi 05 Novemebr 2020, Disetujui 05 November 2020

\begin{abstract}
ABSTRAK
Perkembangan teknologi informasi yang pesat mengubah pola kehidupan pada berbagai aspek. Wujud perkembangannya bisa dilihat pada aspek pendidikan diantaranya pelaksanaan belajar secara online dan evaluasi belajar secara online. Dampak lain dari perubahan tersebut yakni kecenderungan siswa menggunakan media belajar yang disukai, mudah diakses, serta tertarik pada media-media belajar yang interaktif. Pergeseran pola belajar siswa yang demikian menuntut guru untuk mencari serta membiasakan diri untuk menggunakan media belajar interaktif sesuai kebutuhan belajar. Media simulasi interaktif PhET adalah salah satu cara guru menghadirkan pembelajaran interaktif di tengah pembelajaran. Tujuan kegiatan yakni menjaring informasi siswa tentang pembelajaran menggunakan aplikasi simulasi PhET. Topik simulasi dalam kegiatan mencakup kesetimbangan benda, hukum Hooke serta gaya dan gerak benda. Metode yang digunakan dalam kegiatan ini adalah metode simulasi. Evaluasi kegiatan menggunakan angket respon pembelajaran dengan simulasi PhET. Hasilnya menunjukkan $88 \%$ siswa puas terhadap pembelajaran interaktif dengan media PhET. Selanjutnya penggunaan aplikasi interaktif ini diharapkan mampu membangun konsep-konsep fisika dan keterampilan proses sains siswa.
\end{abstract}

Kata kunci: pembelajaran interaktif; simulasi PhET; hasil belajar.

\begin{abstract}
The rapid development of information technology changes the pattern of life in various aspects. The form of its development can be seen in the educational aspects including online learning implementation and online learning evaluation. Another impact of this change is the tendency of students to use learning media that they like, are easily accessible, and are interested in interactive learning media. This shift in student learning patterns requires teachers to seek out and get used to using interactive learning media according to learning needs. PhET interactive simulation media is one way for teachers to present interactive learning in the middle of learning. The purpose of the activity is to collect student information about learning using the PhET simulation application. Simulation topics in activities include the equilibrium of objects, Hooke's law and the forces and motion of objects. The method used in this activity is the simulation method. Evaluation of activities using a learning response questionnaire with a PhET simulation. The results showed that $88 \%$ of students were satisfied with interactive learning using PhET media. Furthermore, the use of this interactive application is expected to be able to build students' physics concepts and science process skills.
\end{abstract}

Keywords: interactive learning; PhET simulation; learning outcomes.

\section{PENDAHULUAN}

Siswa masa kini tumbuh di era digital yang berubah cepat jauh berbeda dengan masa orang tua mereka. Berbagai teknologi, ada di sekitar kehidupan mereka, sehingga mudah bagi mereka menjangkau media- dan menggunakan berbagai teknologi untuk mencari informasi, (NAEYC, 2012). Teknologi digunakan oleh anak-anak dan orang dewasa setiap hari dengan mengunjungi web, jejaring sosial, permainan (game) interaktif, dan masih banyak lagi. Ketergantungan akan inovasi teknologi yang membuat hidup lebih mudah tidak dapat dihindari bahkan sampai di lingkungan sekolah dan perguruan tinggi. Bahkan saat kini, penggunaan teknologi dalam pembelajaran menjadi hal prioritas dan wajib bagi bagi setiap satuan belajar. Menyimak perubahan yang cepat, maka penggunaan media atau aplikasi interkatif menjadi pilihan yang tidak terhindarkan yang dijadikan sebagai pola pendampingan belajar bagi siswa.

Pembelajaran interkatif secara perlahan berubah formatnya yang semula hanya antar siswa dan guru, mulai berkembang menjadi berkembang melalui media interaktif 
yang menjembatani ruang dan waktu. Media interaktif mengacu pada digital dan materi analog, program perangkat lunak (aplikasi), media siaran dan streaming, beberapa program televisi anak-anak, e-book, internet, dan bentuk lainya yang kontennya dirancang memfasilitasi pengguna secara aktif dan kreatif serta mendororong ketelibatan social (NAEYC, 2012). Fokus dalam pembelajaran interaktif bukan pada aplikasi belajar namun tetap pada pengalaman belajar siswa. Praktek belajar dengan aplikasi interaktif akan memperkuat praktek pedagogis guru (Jerusalem, 2019). Mengingat kedudukannya dalam konteks pembelajaran, media interaktif sebagai bagian integral pembelajaran, yang perlu mendapatkan perhatian para guru (Miftah, 2013). Pentingnya media dalam memfasilitasi siswa, penyajiannya disesuaikan dengan tujuan pembelajaran yang ditetapkan.

Penelitian tentang pembelajaran menunjukkan bahwa siswa belajar lebih baik ketika mereka membangun pemahaman sendiri tentang ide ilmiah dalam kerangka pengetahuan yang ada. Untuk mencapai proses ini, siswa harus dimotivasi untuk terlibat secara aktif dengan konten dan harus bisa belajar dari keterlibatan itu. Pada konteks pembelajaran fisika, simulasi komputer interaktif PhET dapat memenuhi kebutuhan tersebut (Carl E. Wieman et al., 2008). Simulasi interaktif $P h E T$ terdiri dari delapan puluh (80) simulasi interaktif yang mencakup topik fisika dan aplikasi dunia nyata, seperti efek rumah kaca dan laser. Simulasi PhET dijalankan browser Web standard dan dapat diintegrasikan dalam kuliah dan sebagai laboratorium virtual. $P h E T$ bisa menjadi alat pembelajaran yang efektif, namun tidak otomatis sukses karena PhET adalah media yang menyempurnakan kurikulum (pembelajaran) yang dirancang guru, (C. E. Wieman et al., 2010).

Pelaksanaan pembelajaran dengan media interakif PhET menjadi bagian dari keseluruhan desain instruksional dengan bimbingan yang tepat dari guru. Penelitian tentang simulasi interaktif PhET sebagai media belajar menunjukkan persentasi keberhasilan yang signifikan,(Saputra et al., 2020), (Anitasari et al., 2019), (Rizaldi et al., 2020; C. E. Wieman et al., 2010). Terungkap bahwa siswa masa kini lebih tertarik menggunakan aplikasi teknologi ketika belajar, belajar menjadi lebih interaktif, transfer pengetahuan menjadi lebih mudah, pikiran cenderung bekerja lebih cepat bila dibantu dengan aplikasi belajar (Wang, 2011)(Uştu, 2014), (Raja \& Nagasubramani, 2018).

Simulasi PhET dalam kegiatan pengabdian menghadirkan laboratorium dalam kelas, sehingga siswa bebas bereksperimen pada konsep-konsep yang disajikan. Kegitan ini sekaligus sebagai langkah solutif bagi guru menanggulangi keterbatasan alat-alat laboratorium. Praktek pembelajaran fisika pada SMA Plus Nusa Timor Kupang seperti lasimnya. Guru menjelaskan konsep tertentu, menurunkan persamaan-persamaan fisika dan mengerjakan latihan-latihan soal. Tujuan kegiatan pengabdian ini yakni memberi informasi tentang penggunaan aplikasi PhET sekaligus membantu guru dan siswa dalam melihat konsep-konsep fisika secara integral.

\section{METODE}

Pelaksanaan kegiatan simulasi PhET berlangsung selama 3 (tiga hari) di sekolah SMA Plus Nusa Timor Kupang. Kegiatan ini diikuti siswa kelas $X$ dan guru fisika. Pendampingan yang dilakukan terdiri dari 2 (dua) dosen pendidikan fisika dan 2 (dua) orang mahasiswa. Pelaksanaan kegiatan hari pertama berlangsung pada Kamis, 18 Mei 2017. Kegiatan hari pertama diawali dengan pemaparan tujuan kegiatan. Simulasi PhET dilaksanakan pada Jumad 19 dan 20 Mei 2017 pada kelas X SMA Plus Nusa Timor. Materi pembelajaran dengan simulasi PhET mencakup elastisitas, gaya dan gerak pada bidang datar, serta tumbukan (momentum dan impuls). Akhir kegiatan dilaksanakan evaluasi pembelajaran menggunakan angket respon siswa terhadap proses pembelajaran menggunakan simulasi interaktif aplikasi PhET yang diberikan.

\section{HASIL DAN PEMBAHASAN \\ Pembelajaran dengan simulasi PhET}

Aplikasi PhET mempunyai banyak topik fisika didalamnya, guru bebas menetukan topik simulasi sesuai kebutuhan pembelajaran. Topik-topik dalam simulasi yang dilaksanakan diantaranya adalah kesetimbangan (balancing art), torka, dan kesetimbangan rotasi. Tujuan simulasi ini (1) siswa memprediksi massa benda dari beberapa variasi massa yang tersedia untuk membuat sistem menjadi seimbang; (2) siswa memprediksi perubahan posisi massa benda pada papan yang berpengaruh terhadap keseimbangan; (3) memprediksi kemiringan papan kesetimbangan; (4) mensimulasi variasi massa untuk melihat perubahan kesetimbangan. 


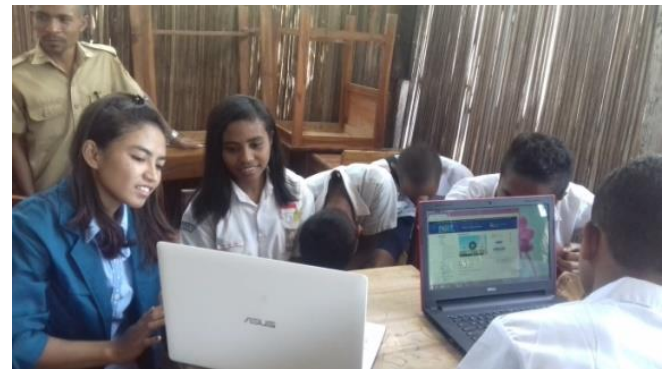

Gambar 1. Pengenalan topik pembelajaran (Sumber: Dokumentasi kegiatan)

Topik simulasi ini terdiri dari tiga bagian yakni pendahulan (intro), laboratorium kesetimbangan (balancing lab) dan permainan (game) yang ditunjukkan dalam kegiatan pada Gambar 1. Siswa terlebih dahulu memahami pola simulasi dan konsep pada bagian intro, sebelum dilanjutkan sampai bagian permainan kesetimbangan yang terdiri dari level 1 sampai level 4.

Keseimbangan (Balancing act) adalah suatu simulasi permainan yang menjelaskan konsep fisika tentang pengaruh massa benda terhadap kesetimbangan, serta pengaruh panjang lengan (kedudukan suatu benda terhadap titik tumpu) terhadap kesetimbangan kedudukan benda. Konsep ini mudah dijelaskan dalam karena bisa ditemukan bahkan sudah mereka lakukan dalam kehidupan mereka (permainan jungkat-jungkit). Simulasi kesetimbangan juga dapat menjelaskan kepada siswa bahwa dalam permainan jungkat-jungkit orang yang massanya lebih kecil dapat mengangkat orang lain dengan massa yang lebih besar, tergantung kedudukan orang tersebut, (simulasi dalam gambar 1).

Simulasi tentang gaya benda (force) and gerak benda (motion) pada gambar 2 menjelaskan beberapa konsep diantaranya konsep gaya, posisi benda (position), kecepatan suatu benda (velocity), dan percepatan gerak benda (acceleration). Tujuan simulasi ini yakni (1) siswa memprediksi pengaruh gaya luar terhadap kecepatan dan arah gerak benda; (2) menjelaskan pengaruhnya melalui diagram; (3) siswa menggunakan diagram untuk menggambar grafik posisi, kecepatan, percepatan dan gaya dan sebaliknya; (4) menjelaskan keterkaitan grafik yang digambar satu dengan lainnya; (5) siswa membuat simulasi grafik untuk topik-topik dimaksud.

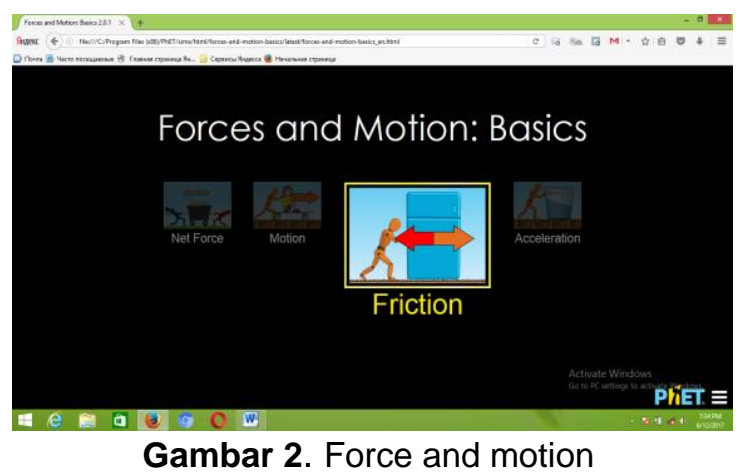

(Sumber: Aplikasi PhET)

Simulasi pada gambar 2 menjelaskan tentang pengaruh gaya terhadap perubahan kedudukan suatu benda, menjelaskan konsep gaya gesek dalam perubahan kedudukan suatu benda yang dihasilkan oleh suatu gaya penggerak suatu benda. Gaya gesek selalu berlawanan arah dengan gaya penyebab gerak benda tersebut.

Pada hukum Hooke (Gambar 3) terdapat beberapa topik simulasi diantaranya tentang pegas, gaya pegas, energy potensial pegas, vector, hukum hooke dan tetapan atau konstanta pada pegas. Simulasi pada gambar 3 , dilakukan dengan meregangkan dan merapatkan pegas untuk mencari hubungan antara gaya, perpindahan, konstanta pegas dan energy potensial. Selanjutnya diselidiki pula apa yang terjadi jika dua pegas dihubungkan secara seri dan parallel, menjelaskan hubungan antara gaya, konstanta pegas, perpindahan dan energi potensial, memprediksi bagaimana energi potensial yang disimpan pada pegas berubah seiring dengan perubahan konstanta pegas dan perpindahan.

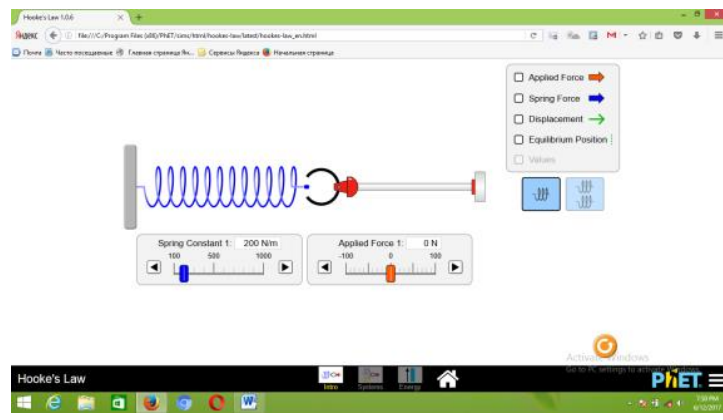

Gambar 3. Hukum Hooke (Sumber: Aplikasi PhET)

Hooke's law atau hukum Hooke menjelaskan konsep elastisitas suatu bahan. Simulasi ini menunjukkan pengaruh gaya terhadap elastisitas pegas.

\section{Respon pembelajaran dengan simulasi PhET}

Respon pembelajaran dengan media interaktif $P h E T$ didapatkan melalui angket respon. Persepsi siswa terhadap pembelajaran 
dengan simulasi ini diwakili dengan jawaban kepuasan siswa. Berikut hasil analisis kepuasan siswa dalam simulasi PhET yang dilaksanakan.

Tabel 1. Analisis Kepuasan Siswa

\begin{tabular}{cc}
\hline Kategori Kepuasan & Persentasi (\%) \\
\hline Puas & 88 \\
\hline Tidak Puas & 12 \\
\hline
\end{tabular}

Kegiatan simulasi PhET memberi kesan pembelajaran fisika yang menyenangkan pada siswa serta guru fisika. Lebih dari separuh siswa yang mengikuti pembelajaran menyatakan puas mengikuti pembelajaran dengan metode ini. Berdasarkan Tabel 1, sebanyak $88 \%$ siswa menginginkan bahwa pelajaran fisika harusnya dibuat dalam bentuk permainan atau simulasi yang menyenangkan mereka dalam belajar. Sementara guru fisika selaku pendamping dalam kegiatan ini mengharapkan bahwa kegiatan simulasi ini hendaknya selalu diberikan pada kegiatankegiatan berikutnya. Pelatihan simulasi ini juga memberikan pencerahan bagi guru fisika dalam membelajarkan fisika kepada siswa di kelas. PhET sebagai media interaktif berdampak positif pada pembelajaran, siswa menjadi lebih terlibat dalam belajar sehingga siswa dapat menyimpan lebih banyak informasi.

\section{SIMPULAN DAN SARAN}

Kegiatan pengabdian masyarakat berupa pendampingan simulasi media interaktif PhET dengan 26 siswa peserta di SMA plus Nusa Timor Kupang dilaksanakan selama 3 (tiga) hari. Hasil pelaksanaan kegiatan ini (1) siswa teredukasi dalam pembelajaran fisika melalui media-media interaktif sebagai pilihan baginya dalam belajar khusunya pada materi gaya dan gerak benda, kesetimbangan benda, dan gaya pada pegas; (2) lebih dari 80 persen siswa menyatakan puas dengan pembelajaran melalui aplikasi interaktif ini (3) guru dapat menjadikan aplikasi interaktif PhET dalam pembelajarannya sebagai salah satu solusi untuk pembelajaran yang interaktif dan menyenangkan.

\section{UCAPAN TERIMAKASIH}

Tercapainya kegiatan pengabdian masyarakat ini berkat kerja sama beberapa pihak terkait. Ucapan Terima kasih kepada pihak LPPM Universitas Katolik Widya Mandira Kupang yang telah mendanai kegiatan pengabdian pada masyarakat.

\section{DAFTAR RUJUKAN}

Anitasari, B., Winarti, A., \& Rusmansyah, R. (2019). MEDIA SIMULASI PhET (PHYSICS EDUCATION TECHNOLOGY) UNTUK
MEREDUKSI MISKONSEPSI SISWA PADA KONSEP ASAM BASA. Quantum: Jurnal Inovasi Pendidikan Sains, 10(1), 8. https://doi.org/10.20527/quantum.v10i1.571 3

Jerusalem, E. (2019). Children, technology and teaching. 55-80.

Miftah, M. (2013). Fungsi, Dan Peran Media Pembelajaran Sebagai Upaya Peningkatan Kemampuan Belajar Siswa. Jurnal Kwangsan, 1(2), 95. https://doi.org/10.31800/jurnalkwangsan.v1i 2.7

NAEYC. (2012). Technology and Interactive Media as Tools in Early Childhood Programs Serving Children from Birth through Age 8. Children, January, 1-15. http://www.naeyc.org/positionstatements

Raja, R., \& Nagasubramani, P. C. (2018). Impact of modern technology in education. Journal of Applied and Advanced Research, 3(S1), https://doi.org/10.21839/jaar.2018.v3is1.16 5

Rizaldi, D. R., Jufri, A. W., \& Jamal. (2020). PhET: SIMULASI INTERAKTIF DALAM PROSES PEMBELAJARAN FISIKA. Jurnal IImiah Profesi Pendidikan, 5(1), 10-14. https://doi.org/10.29303/jipp.v5i1.103

Saputra, R., Susilawati, S., \& Verawati, N. N. S. P. (2020). Pengaruh Penggunaan Media Simulasi PhET (Physics Education Technology) Terhadap Hasil Belajar Fisika. Jurnal Pijar Mipa, 15(2), 110. https://doi.org/10.29303/jpm.v15i2.1459

Uştu, H. (2014). No 主镜的健康感を中心とした 在宅高齢者における 健康関連指標に関する 共分散 構造分析 Title. https://doi.org/10.1038/132817a0

Wang, L. N. (2011). Impact of information technology on accounting. Advanced Materials Research, 219-220(131), 12241227.

https://doi.org/10.4028/www.scientific.net/A MR.219-220.1224

Wieman, C. E., Adams, W. K., Loeblein, P., \& Perkins, K. K. (2010). Teaching Physics Using PhET Simulations. The Physics Teacher, 48(4), 225-227. https://doi.org/10.1119/1.3361987

Wieman, Carl E., Adams, W. K., \& Perkins, K. K. (2008). Physics. PhET: Simulations that enhance learning. Science, 322(5902), 682683.

https://doi.org/10.1126/science.1161948 